\title{
The Steno Medal
}

\author{
OLE GRAVERSEN
}

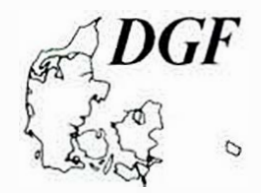

Graversen, O.: The Steno Medal. Bullerin of the Cieological Society of Denmark. Vol. 41 , pp. 117-122. Copenhagen. 1994-11-30. https://doi.org/10.37570/bgsd-i 995-41-20

The Steno Medal was founded by the Geological Society of Demmark in 1969 on the 3(0)(th anniversary of the publication of Nicolai Stenonis: De solide intra solidum naturaliter comtente. The original models for the medal were sculptured by royal medallist Harald Salomon. The decision to found the medal was reached by the Geological Society in 1968 after five years of deliberations. The portrait of Steno hung in the Galleria Uffizi in Florence is the sottrce of the obverse of the medal. while the quartz crystals figured on the reverse side are from the collection of the Geological Museum. Copenhagen. The Steno Medal is awarded to foreign geologists, in special cases Danes, who have made outstanding contributions within the geological sciences. The medal was presented for the sixth time at the 100 years anniversary symposium of the Geological Society of Denmark in 1993.

An analysis of the title pange of Steno's manuscript and of the Ist edition of De solide have lead to a revision of the title in its most frequently used form.

Ole Graversen. Geological Instinute. University of Copenhagen. Oster Voldgade 10. DK-1.350 Copenhagen K, Denmark. Ocrober 12th. 1994.

\section{Introduction}

The Steno Medal is a gold medal founded by the Geological Socicty of Denmark in order to honour foreign geologists, in special cases Danes, who have made significant contributions within the field of the geological sciences.
The charter of the Steno Medal is published (in Danish) by the Geological Society ol Denmark (Dansk Geologisk Forening, 1971). The founding of the Steno Medal was made possible by donation from Kryolitselskabet Øresund $\mathrm{A} / \mathrm{S}$.

The medal was instituted in 1969) to mark the 30)th
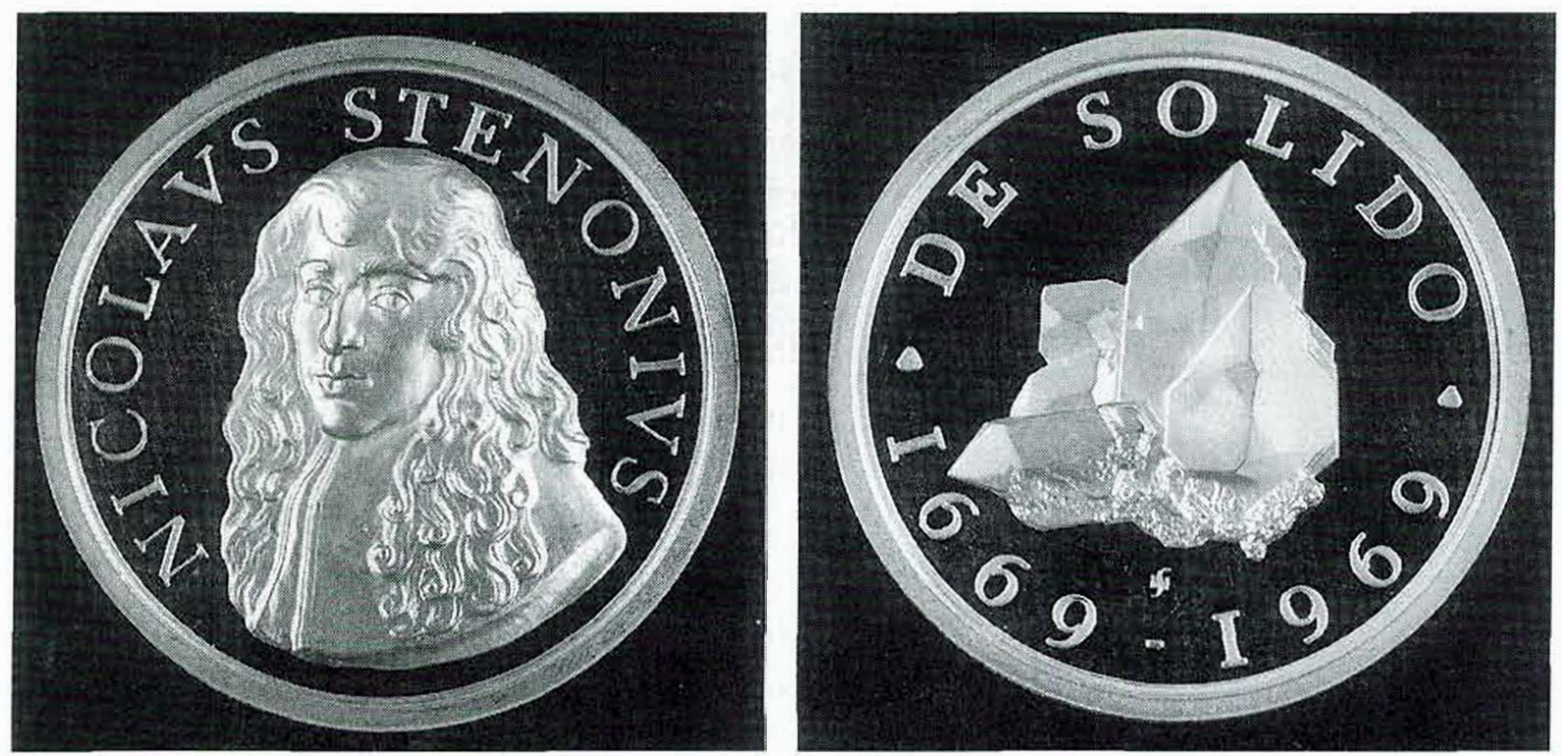

Fig. 1. The Steno Medal. The obverse (lefi) bears the portrait of Niels Steensen while the reverse side represents a group of guartz crystals. The sandblast reliefs are raised above a plane, blank background (fleur-de-coin technique). The artislic design was by the royal medallist Harald Salomon. The diameter of the medal is $50 \mathrm{~mm}$ and the gold weight is 1() 4 grammes. Photo Ole B. Berthelsen. 


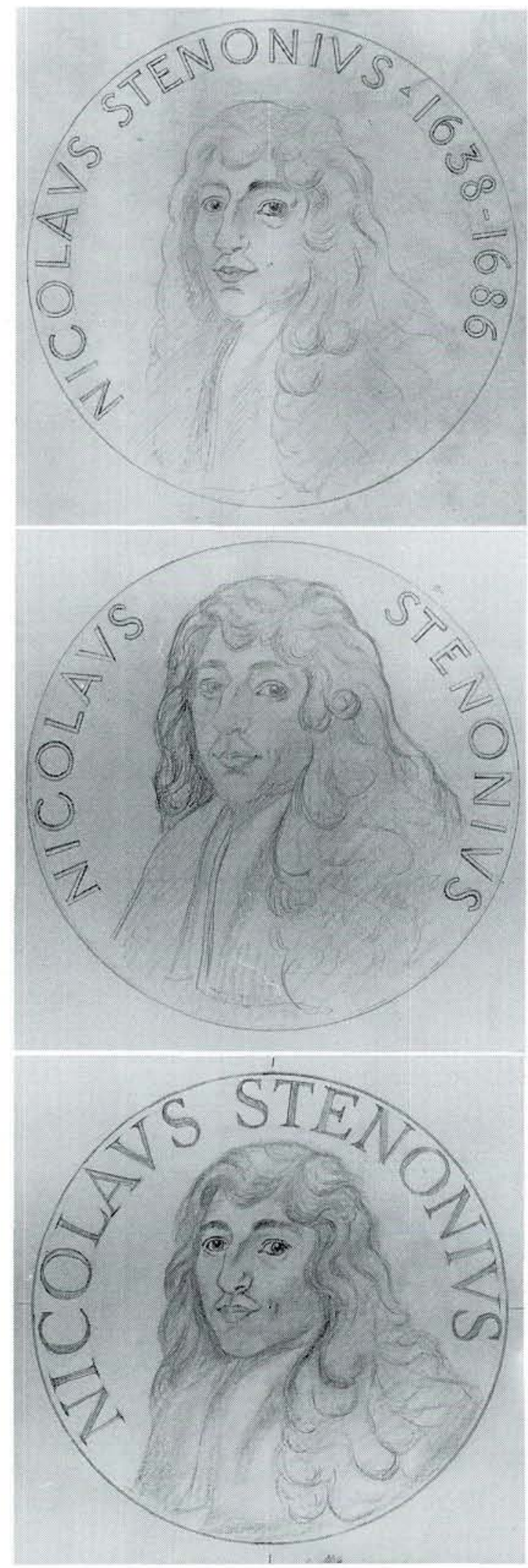

anniversary of the publication of Nicolai Stenonis: "De solido intra solidum naturaliter contento" (On solids naturally contained within solids). Nicolai Stenonis is the Latin version of his original Danish name Niels Steensen. In the present paper the spelling of Niels Steensen's name in Danish is according to Kallan (1991) and in Latin is taken from the title page of De solido. In everyday usage Niels Steensen is usually just spoken of as Steno. Hoch (1985) has given an outline of Steno's life, his travels, and his scientific activities in the years around the publication of De solido. Two comprehensive works on Steno as a geologist and his geological papers were edited by Scherz $(1969,1971)$. A review biography of Steno is that (in Danish) by Snorrason (1983). A reconsideration of Steno's life and scientific work by Danish scientists has been edited by Poulsen \& Snorrason (1986).

\section{Background}

In the records of the Geological Society of Denmark the idea of inaugurating a Steno Medal was referred to for the first time in the minutes of a liaison committee meeting in March 1963. This was the first formal meeting between the executive committee and representatives of the specialized scientific clubs attached to the Society. During the discussions Professor Hans Pauly made the suggestion that there should be a means of honouring persons within the Geological Society. This idea had previously been aired by the late Professor Arne Noe-Nygaard and Hans Pauly himself. It was discussed whether to establish a Steno Medal to be awarded to foreign geologists while a Bartholin Medal could be established to honour Danish geologists. It was further suggested that a pecuniary reward might be attached to the medal awards. The next mention of the medals in the official annals of the Society was not until the preparation of the agenda for a liaison meeting under the chairmanship of Professor Henning Sørensen in October 1968. In December the proposal was discussed by the liaison committee. At this meeting there was full agreement on the proposal to establish the Steno Medal while it was decided not to proceed with the Bartholin Medal. The Steno Medal was established under the presidency of the late Professor Tove Birkelund during the spring of 1969. The funds received from Kryolitselskabet Øresund A/S covered the expenses of the design as well as striking the medal. The charter of the Steno Medal was approved at an extraordinary general meeting in April. The first medal was presented at a symposium held by the Geological Society in October 1969.

Fig. 2. Pencil sketches of the obverse of the medal with the portrait of Steno drawn by Harald Salomon. The diameter of the original drawings varies between 207 and $215 \mathrm{~mm}$. Photo Ole B. Berthelsen. 


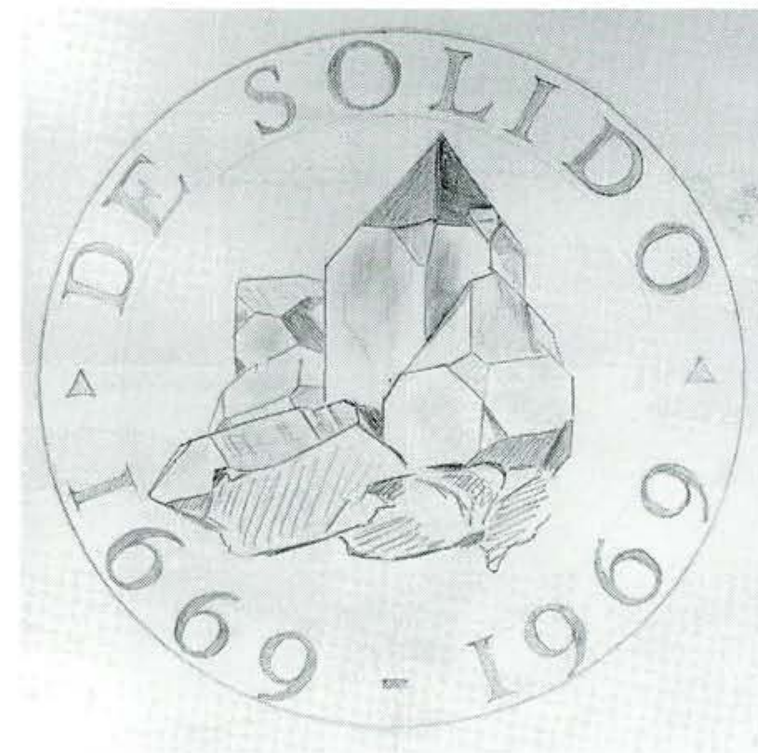

Fig. 3. Pencil sketch of the reverse side of the medal illustrating quartz crystals. Drawing by Harald Salomon. The diameter of the original drawing is $210 \mathrm{~mm}$. Photo Ole B. Berthelsen.

\section{Artistic design}

The artistic design of the Steno Medal was executed by the late royal medallist Harald Salomon. The obverse of the medal shows a portrait of Steno while the reverse side shows a group of quartz crystals to illustrate Steno's crystallographic law of constant interface angle (Fig. 1). The artist made a model of the medal which subsequently in the normal technical way was converted to dies. The reliefs of both the obverse and reverse are sandblast and raised above a plain, blank background (fleur-de-coin). The dies to strike the medal are kept at the Royal Mint.

At a meeting in February 1969 the executive committe of the Geological Society agreed that the design of the medal should follow a Steno relief at that time decorating one of the exhibition halls in the Geological Museum. Thomasen (1975) published a picture of the relief together with a short description of the known history of the relief. However, by comparing the portrait in the relief with that on the medal, it is quite obvious that the relief did not serve as a model for the medal. The model for the medal is to be found in the "official" portrait painting of Steno. This portrait is hung in the Galleria Uffizi in Florence and it is often referred to as the only authentic portrait of Steno. A painted copy of this Steno portrait belonging to the Anatomical Institute, University of $\mathrm{Co}$ penhagen, has been reproduced in Poulsen \& Snorrason (1986) and Rafaelsen (1987).

Three of Harald Salomon's hand-drawn studies for the obverse of the medal made prior to the engraving of the medal dies are reproduced in Fig. 2. The Steno portrait in all three drafts follows the authentic painted portrait fairly

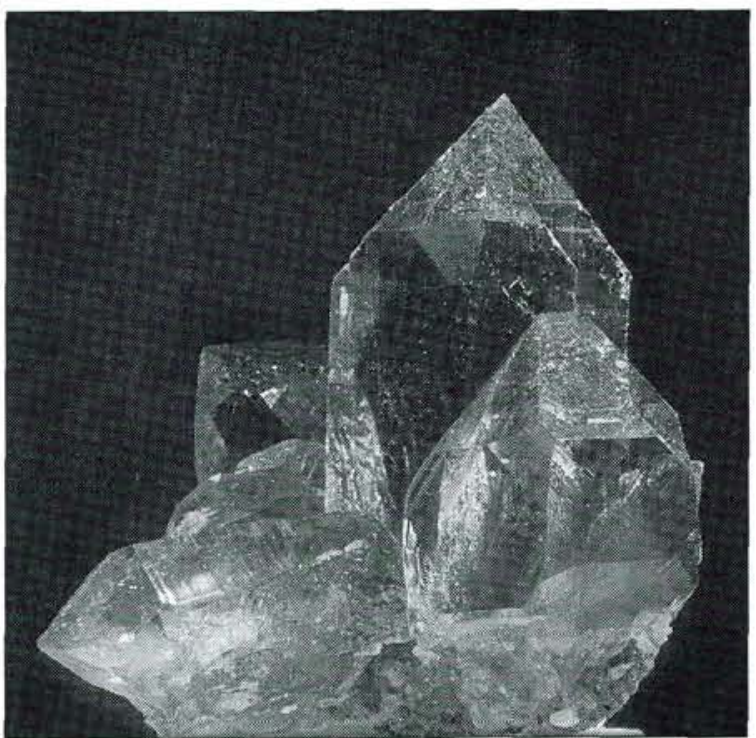

Fig. 4. Group of smokey quartz crystals from Alençon, France. This specimen from the Geological Museum, University of Copenhagen, served as a model for the reverse side of the Steno Medal. Photo Ole Johnsen.

closely. The drawings, however, illustrate how Harald Salomon worked with the typography and with the balance between the portrait and the text. In the final draft the typography is very close to the typography used by the artist who painted the "official" Steno portrait.

The reverse side of the medal commemorates the first edition of Nicolai Stenonis' "De solido intra solidum naturaliter contento" (1669). In this paper Steno demonstrated the crystallographic law of constant interface angle. On the medal this concept is illustrated by a group of quartz crystals while the text refers to the original publication and the 300 years anniversary of this publication. Harald Salomon's original draft of the reverse side of the medal is reproduced in Fig. 3. The model used for the hand-drawn study and the later engraving has been identified as a specimen of smokey quartz crystals from Alençon, France, in the collections of the Geological Museum in Copenhagen (Fig. 4).

\section{The title of De solido}

When reference is made to the original Steno (1669) dissertation on solids the title is usually referred to as " $D e$ solido intra solidum naturaliter contento dissertationis prodromus". The preliminary character of the paper (dissertationis prodomus) is thus implied in the title. This has also been the case in most translations (see bibliography in Scherz 1969). In the English translation from 1671 the title is "The Prodromus to a Dissertation Concerning Solids Naturally Contained within Solids". The Danish translation from 1902 by August Krogh and Vilhelm 


\section{NICOLAI STENONIS D E SOLI D O}

INTRA SOLIDVM NATVRALITER CONTENTO DISSERTATIONIS PRODROMVS.

$\triangle D$

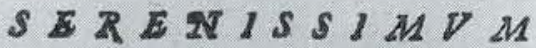 \\ FERDINANDVM II. MAGNVM ETRVRIAR DVCEM:}

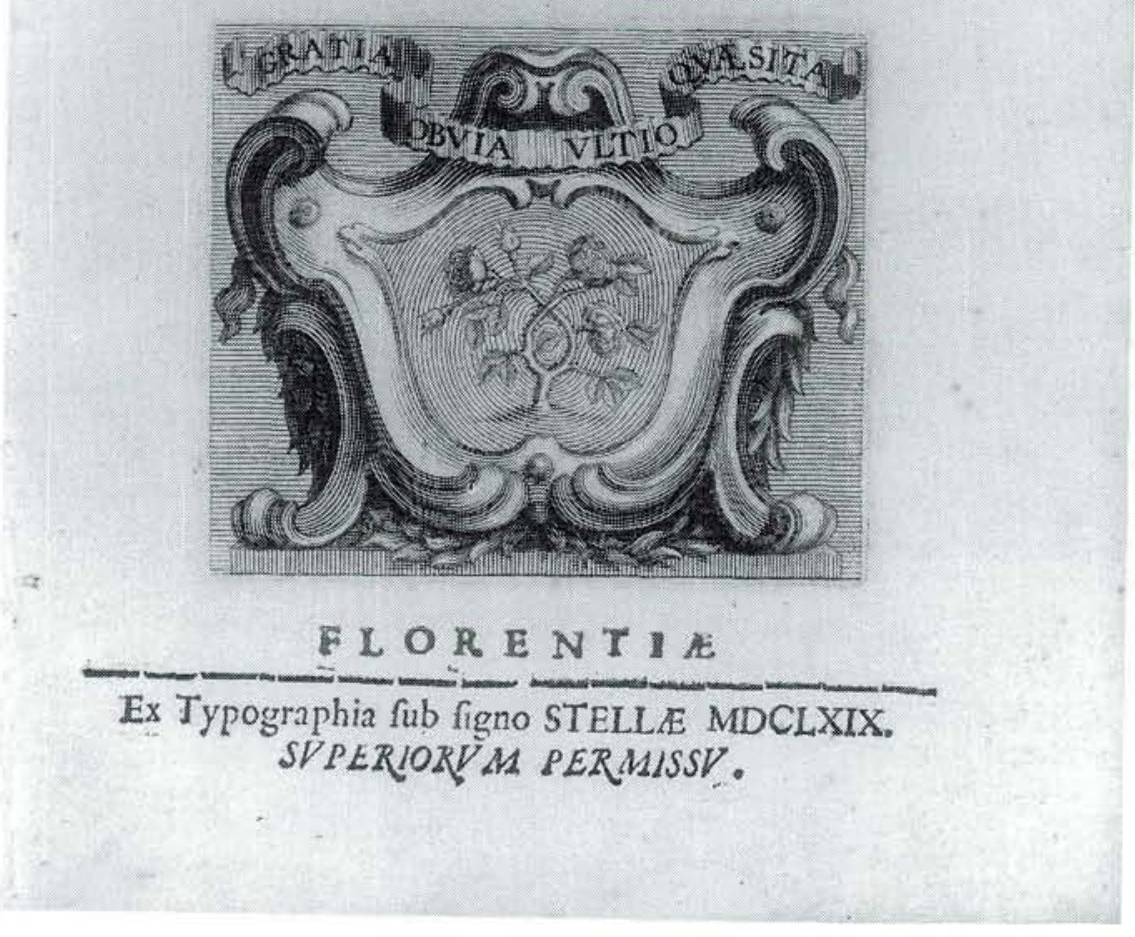

Fig. 5. Title page of Nicolai Stenonis' De solido intra solidum naturaliter contento. Dissertationis prodromus. 1st edition, Florence 1669. The lines "Nicolai Stenonis",

"Dissertationis prodromus", "Ferdinandum II" and "Florentia" are all printed in red while the remaining text is printed in black. The book is printed in the $4^{\circ}$ format (original size is $161 \times 233$ $\mathrm{mm})$. Photo of the copy in the Geological Museum,

University of Copenhagen, by Ole B. Berthelsen.
Maar follows the same lines: "Foreløbig Meddelelse til en Afhandling om faste Legemer, der findes naturlig indlejrede i andre faste Legemer". As a consequence, mention of this Steno dissertation has usually referred to it as either the De solido or as the Prodromus.

Although Steno himself indicated that his paper $D e$ solido was a preliminary communication (dissertationis prodromus), this implication was never a part of the title itself. On the title page of the first edition (1669) (Fig. 5) "Nicolai Stenonis" and "Dissertationis prodromus" are printed in red while the title printed between these two lines is printed in black. This indicates that the proper title is restricted to De solido intra solidum naturaliter contento. The addition Dissertationis prodromus should therefore be read as a note added to indicate the nature or status of the paper. This view is in accordance with the title page of the original manuscript where the title is written

De Solido intra solidum naturaliter contento Dissertationis prodromus

(reproduced from a photo of the original handwritten manuscript in Scherz (1969)). In the hand-written manu- 
Fig. 6. Presentation of the Steno Medal to Professor John H. Callomon, University College, London, (left) by Ole Graversen, symposium chairman and vicepresident of the Geological Society of Denmark.

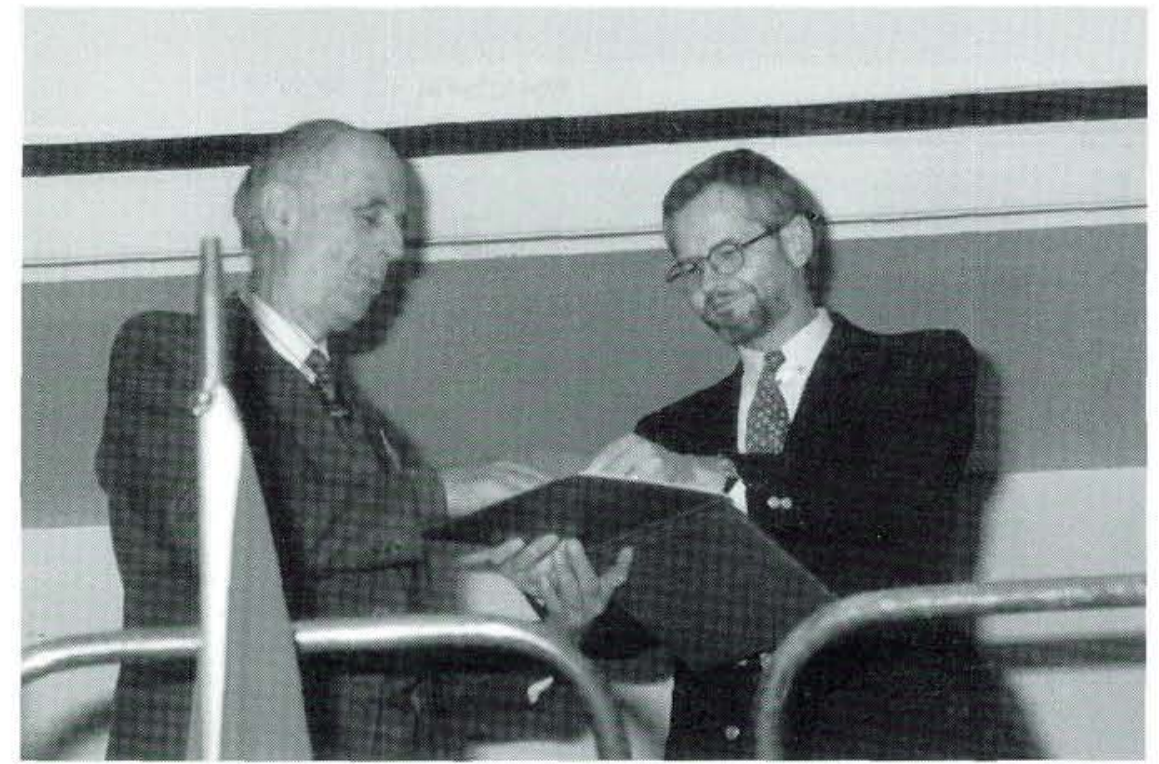

script Dissertationis prodromus is separated from the title by extra spacing and it starts with a capital D. An analysis of the Latin grammar of the title likewise indicates that Dissertationis prodromus is not a part of the title proper (Peter Ørsted, personal communication). The title of Steno's 1669 dissertation should therefore be restricted to $D e$ solido intra solidum naturaliter contento (short version: De solido). Translations should follow this line and the title in English would thus be On solids naturally contained within solids (short version: On solids).

\section{Medal awards}

The Steno Medal was presented for the first time in 1969. Until the 100th anniversary of the Geological Society the medal was awarded every five years which is the maximum interval allowed according to the charter. The medal has been awarded to the following geologists (with their main fields of interest indicated):

1969: Sigurdur Thorarinsson, Iceland (vulcanology, tephra chronology),

1974: John Haller, Switzerland (tectonics, East Greenland Caledonides),

1979: Stephen Moorbath, Great Britain (isotope geology, dating of the Precambrian of West Greenland),

1984: Jörn Thiede, Germany (ocean sediments, Tertiary palaeooceanography of the North Atlantic),

1989: Victor R. McGregor, New Zealand/Denmark/Greenland (Precambrian basement geology, the Archaean of West Greenland).

The cost of the striking all of these medals was covered by donations from Kryolitselskabet Øresund A/S.

In 1993 the Steno Medal was presented to Professor John H. Callomon, University College, London, at the 100 years anniversary symposium of the Geological So- ciety (Figure 6). The medal was awarded to John Callomon in recognition of his outstanding contribution to the Mesozoic stratigraphy and palaeontology of East Greenland through his studies on Jurassic and Cretaceous ammonites. A more comprehensive description of John Callomon's work in East Greenland is given by Surlyk (1994, this volume). In the jubilee year of the Geological Society of Denmark the Geological Society found John Callomon especially qualified to receive the Steno Medal since he in a positive way combines (1) the "spirit of Steno", as John Callomon is strictly speaking an amateur palaeontologist (John Callomon is a chemist by education and profession), (2) he links back to an early exploration phase of East Greenland geology as he was a participant in the Lauge Koch expeditions in the 1950's, and (3) up to the present time he has had close connections to Denmark through his collaboration with the Geological Institute as well as the Geological Museum at the University of Copenhagen.

\section{Acknowledgements}

During the preparation of the manuscript the author has dealt with a number of subjects not familiar to him. The author is therefore grateful for the help he received from keeper of coins Jørgen Steen Jacobsen, Royal Collection of Coins and Medals, National Museum of Denmark, lektor Ole Johnsen and lektor Ella Hoch, Geological Museum, and lektor Peter Ørsted, Department of History, University of Copenhagen. During the preparation for the medal award as well as this article, the author benefited from the notes in the archives by Chris Pulvertaft, former President of the Geological Society. Chris Pulvertaft kindly improved the English language. 


\section{Dansk sammendrag}

Steno medaljen blev grundlagt af Dansk Geologisk Forening i 1969 i anledning af 300 året for udgivelsen af Stenos (Niels Steensens) De solido intra solidum naturaliter contento. Kgl. hofmedaljør Harald Salomon stod for den kunstneriske udformning af medaljen. Beslutningen om at indstifte Steno medaljen blev taget af Geologisk Forenings bestyrelse i 1968 efter en længere modningsproces. Portrattet af Steno i Galleria Uffizi i Firenze har dannet forlæg for medaljens forside, medens kvartskrystallerne på bagsiden er tegnet efter forlæg fra mineralsamlingen i Geologisk Museum. Steno medaljen kan tildeles udlændinge, og i særlige tilfælde danske, som har ydet betydningsfulde bidrag inden for de geologiske videnskaber. Ved Dansk Geologisk Forenings 100 års jubilæum i 1993 blev medaljen uddelt for 6. gang.

En analyse af titelbladet fra Steno's manuskript til og 1. udgave af De solido har ført til en revision af titlen $\mathrm{i}$ dens hyppigst anvendte form.

\section{References}

Dansk Geologisk Forening 1971: Steno Medaljen. Dansk Geologisk Forening, Årsskrift for 1970, 109-110.

Hoch, E. 1985: - on Steno. Dansk Geologisk Forening, Årsskrift for $1984,79-86$

Kallan, K 1991: Wie heisst Niels Steensen eigentlich? Dänische Namenssitten im 17. Jahrhundert. Stenoniana-nova series 1, 152-158.

Poulsen, J.E. \& Snorrason, E. (eds) 1986: Nicolaus Steno 16381686. A Re-consideration by Danish Scientists. 224 pp. Nordisk Insulinlaboratorium.

Rafaelsen, O. 1987: Niels Stensen - som en fakkel i mørket. Naturens. Verden, 3-8. Rhodos.

Scherz, G. (ed.) 1969: Steno, geolgical papers. Acta Historica Scientiarum Naturalium et Medicinalium. Editit Bibliotheca Universitatis Hauniensis 20,1-370. Odense University Press.

Scherz, G. (ed.) 1971: Steno as geologist. Acta Historica Scientiarum Naturalium et Medicinalium. Editit Bibliotheca Universitatis Hauniensis 23, 1-319. Odense University Press.

Snorrason, E. 1983: Niels Stensen. Dansk biografisk leksikon. Gyldendal 1983 .

Stenonis, N. 1669: De solido intra solidum naturaliter contento. Dissertationis prodromus. $78 \mathrm{pp}, 1$ Plate. Florence.

Surlyk, F. 1994: Presentation of the Steno Medal to Professor John H. Callomon, London, UK. Bulletin of the Geological Society of Denmark 41, 123-125 (this volume).

Thomasen, A.-L. 1975: Nicolaus Stenonius - anatomicus geologicusque maximus. Dansk Geologisk Forening, Årsskrift for $1974,1-4$. 